\title{
Slovenian Example of Bilingual Primary Education
}

\author{
Vlasta Hus, Polona Jančič \\ Faculty of Education, University of Maribor, Maribor, Slovenia \\ Email:vlasta.hus@um.si,polona.jancic1@um.si
}

How to cite this paper: Hus, V., \& Jančič, P. (2018). Slovenian Example of Bilingual Primary Education. Creative Education, 9, 1-10.

https://doi.org/10.4236/ce.2018.91001

Received: December 8, 2017

Accepted: January 9, 2018

Published: January 12, 2018

Copyright $\odot 2018$ by authors and Scientific Research Publishing Inc. This work is licensed under the Creative Commons Attribution International License (CC BY 4.0).

http://creativecommons.org/licenses/by/4.0/

\section{c) (i) Open Access}

\begin{abstract}
In the last 50 years, models of bilingual education with members of national minorities have been at the centre of political, social, and economic debates. Education is an important area where two languages systematically meet. This article introduces researches already made on the planning and performing classes in bilingual primary schools and presents bilingual model used in Slovene primary schools. Performing bilingual primary education in Slovenia is a challenge for teachers because they demand special organization and content to achieve their goals. Bilingual education belongs to the two-way model of preserving two languages and cultures. Bilingual classes are attended by students of two nationalities and mother tongues. Both languages are taught and have an equal status in all subjects. At the same time, both languages have an equal position as means of spoken and written communication inside and outside of the school.
\end{abstract}

\section{Keywords}

Primary School, Education, Bilingual, Model, Slovenia, Learning

\section{Introduction}

This article introduces the features of linguistic and ethnic contacts in Slovenia focusing on primary education. Education is an important area where two languages systematically meet. Bilingual education is not a modern phenomenon because it has been present in this area since the 1960s. This form of education demands a qualified teacher who can search for an appropriate model and method of communication. We are presenting Slovenian example of a bilingual model supported with some results of previous research which addresses the problems of bilingual education. Topic is significant because due to the increase of bilingual families, there is also an increase of children entering the education- 
al system with various amounts of bilingual knowledge.

The Republic of Slovenia has a special Roma community and two national minorities (the Italian and the Hungarian national community). All three communities are protected by the constitution (Articles 64 and 65 of the Constitution of the Republic of Slovenia, 2016). This article focuses on the organization of the bilingual model in primary education of the Hungarian national community. The autochthonous settlement area of Hungarians is in northeast Slovenia. In the 2002 census posted by the Republic of Slovenia Statistical Office, 6243 persons stated that they were members of the Hungarian national community; 7713 persons stated that the Hungarian language was their mother tongue (http://www.stat.si/StatWeb/en). In accordance with the legal order of the Republic of Slovenia (http://www.pisrs.si/Pis.web/pregledPredpisa?id=ZAKO2611), the Hungarian national community in Slovenia is organized within the Pomurje Hungarian self-governing community. Its headquarters is in Lendava. This is an umbrella organization of the Hungarian national community in the Republic of Slovenia. It has 21 members and communicates with state authorities. Schools in the ethnically mixed areas in which the Hungarian national community resides must be bilingual by law. That affects also education which has to be conducted in both Slovene and Hungarian language for all residents of the area. Therefore, a bilingual model in primary education is used in Slovenian linguistic and ethic intersections and which we are presenting in our article-starting with some history backgrounds for better understanding.

\section{Linguistic and Ethnic Intersection}

In the past, Slovenia has witnessed modern integration processes that continue to cause a shift in ethnic identity. The term "ethnicity" (the word derives from the Greek word ethnos and means people) has been interpreted in different ways by theorists (Smith, 1991):

- a minority community;

- characteristics of a community in the process of developing a common social identity based on common origin, culture, language, or religion;

- characteristics of communities related to common culture.

Until now, the identification of individuals with one's nation has been sufficient for the existence of a nation in a national state. In new conditions, a higher level of active ethnic identity becomes more important, including national identity and attitude toward members of other national communities (Mikolič, 2000). National consciousness can be a solid foundation on which a national community and its members strengthen their national self-confidence, as well as their cultural, political, and economic identity and equal cooperation with other national communities.

The Hungarian national community is settled in northeast Slovenia. Called Hungarians of Prekmurje, the area is the autochthonous settlement area of Hungarians in Prekmurje. Both terms established themselves after World War II 
due to the need for standard designation. Furthermore, the terms "nationally mixed area" and "bilingual area" were used. The Hungarian minority was granted rights on the nationally mixed area. Originally, the nationally mixed area in Prekmurje was not bilingual, as the villages and settlements were either Slovenian or Hungarian (Bernjak, 2004). After World War I, in accordance with the Treaty of Trianon, the Hungarian minority was given the right to use their own language in school. Later, the Socialist Federal Republic of Yugoslavia (SFRY) adopted the model of education so that the children of Hungarian nationality were educated separately with Hungarian as the language of instruction. After World War II, as parents chose Slovenian departments, SFRY sought improved models of education as the number of children enrolled with Hungarian as the language of instruction decreased. Consequently, secondary education with Hungarian as the language of instruction seemed unreal. The bilingual concept of ethnically and linguistically mixed classes followed the example of Swiss practice (NećakLük, 2010). Schools in ethnically mixed areas where the Hungarian national community resides must be bilingual by law (classes are conducted in both Slovene and Hungarian for residents).

Due to the increase of bilingual families, there is also an increase of children entering the educational system with various amounts of bilingual knowledge. The position of the minority language in the educational system can vary in ethnically heterogeneous environments. This means that the language is (Novak-Lukanovič \& Zver, 2013):

- The language of instruction

- The school subject

- Compulsory or optional subject

New guidelines for bilingual education were developed after the reform of the Slovenian school system in the 1990s and the introduction of nine-year primary education. As regulated by the Elementary School Act

(https://www.uradni-list.si/glasilo-uradni-list-rs/vsebina?urlurid=20063535\#), both Slovenian and Hungarian are taught as subjects at all levels. Both are used as the language of instruction. Bilingual schools practice the one person-one language strategy and work in small groups where both mother tongues play an equal role and students' first language is strengthened (NećakLük, 2010, 2013). With both countries being members of the European Union, the approaches enable the members of the Hungarian national community to continue their secondary and higher education in Slovenia or Hungary. As for the members of Slovenian national community, knowledge of Hungarian language represents an advantage and added value.

Bilingual education in Slovenia reflects the respect for others and signifies equality for ethnic groups. It is a cultural and linguistic knowledge of either majority or minority.

\section{The Model of Bilingual Primary Education}

Bilingual primary education in the nationally mixed area of Prekmurje was in- 
troduced in 1959. Between 1945 and 1959, classes in Hungarian and Slovenian national schools were conducted separately in their own mother tongues. In the third class, the majority language was taught four hours a week. Furthermore, the national language was introduced and confirmed as a school subject. Teachers and students had to be members of the same national community. The national language, however, was only used for internal operations of the school. This form of education could neither protect Hungarians living in this area nor ensure their existence due to subjective and objective factors (Hozjan, 2009).

Therefore, the model of bilingual primary education was introduced to improve the level of education. It also addressed the increased number of children of the Hungarian national community whose parents enrolled them in Slovenian rather than Hungarian departments. The bilingual education system was introduced also to protect the future of autochthonous Hungarians as a minority. Bilingual schools in the nationally mixed areas included students of Slovenian and Hungarian nationality, which gave them opportunities to learn both languages and the historical and cultural achievements of both nations (Varga et al., 2005). In the last 50 years, the educational models, including the members of national minorities, have been the centre of political, social, and economic debates. This affected their changing and developing processes. Education is one of the most important areas where two languages can systematically meet (Novak-Lukanovič \& Zver, 2013). The methodology of the language organization usually includes at least three basic principles of language organization in classes: 1) associate; 2) separate; and 3) parallel. In all three examples, this work discusses bilingual education. However, the separate and parallel principle includes two languages. This means that they serve as languages of instruction and, at the same time, one of them (both in mixed departments) is the students' first language (NećakLuk, 2013).

European examples have confirmed the use of bilingual education models in separate environments, which have, from the individual's and society's point of view, different objectives (Anckar, 2000; Novak-Lukanovič \& Zver, 2013; Ouane, 2003). Every model of education is the result of social and political indicators. Specifics of a minority must be considered. Therefore, a standard model does not exist. The term "bilingual education" can have different meanings in terms of organization, content, and objective (Novak-Lukanovič \& Zver, 2013). The model of bilingual education is a two-way model maintaining two languages and cultures. Bilingual classes are attended by students of two nationalities and two mother tongues. Both languages are taught subjects and languages of instruction. They have an equal position as means of spoken and written communication in and outside of school, as well as formal communication. The programme is added various contents related to the history and the culture of the other nation (NećakLuk, 2013).

\section{Education in Bilingual Primary Schools}

In Slovenia students of two nationalities and mother tongues attended bilingual 
classes and use both languages as their taught subjects and languages of instruction in primary schools which are called Billingual primary schools. Bilingual primary schools and their affiliated schools in Slovenia include: 1) Bilingual Elementary School Lendava I with affiliate schools in Gaberje, Petišovci, and Čentibi; 2) Bilingual Elementary School Lendava II with a special programme; 3) Bilingual Elementary School Genterovci; 4) Bilingual Elementary School Dobrovnik; and 5) Bilingual Elementary School Prosenjakovci with affiliate schools in Domanjševci and Hodoš. According to the Slovenian Statistical Office, 744 students attended bilingual primary schools in school year 2014/2015. In school year 2005/2006 855 students enrolled in the educational system.

As part of the curriculum, a bilingual primary school must provide two educational objectives:

1) An instrumental objective to enable integration into social life and acquire knowledge for life and work.

2) An expressive objective connected to the social-cultural values and creativity of an individual.

The main objective of Slovenian bilingual education is to provide a quality educational to give students equal opportunities to continue their education. In turn, it ensures equal possibilities for social development of the national minority. The equal status of both mother tongues as subjects and languages of instruction is the basis for the development of two-way bilingualism (or functional bilingualism). Both models preserve and enrich the ethnic identity of an individual and aim to achieve cultural pluralism/intercultural dialogue and two-way bilingualism (Novak-Lukanovič \& Zver, 2013).

Bilingual education in bilingual primary schools is based on:

- the adapted and updated curriculum and lessons plan,

- qualified professional staff that is fully competent in both languages and improves its knowledge in both languages,

- the method of the bilingual education,

- bilingual textbooks and teaching material,

- additional teaching resources and teaching equipment for the national programme,

- adopted norms and standards (Varga et al., 2005).

According to the Act Regulating Special Rights of Members of the Italian and Hungarian Ethnic Communities in the Field of Education, the bilingual education in nationally mixed areas includes the following:

- Preservation and development of Italian or Hungarian language and the culture of an Italian and Hungarian national community.

- Development of proficiency in both languages (for members of the national communities, Hungarian or Italian represent their first language and Slovenian their second).

- Development of knowledge in history, culture, and natural heritage of Hungarian or Italian national community and their countries of origin. 
- Development of Hungarian or Italian national community awareness and preservation and development of one's own cultural tradition.

- Education for respecting and understanding the national and cultural differences for collaboration between the members of Slovenian national majority and Hungarian or Italian national communities and developing the ability for cohabitation in ethnically and linguistically mixed areas.

- Introduction of the position of Hungarian and Italian national communities in neighbouring countries and establishment of links and cooperation with members of these communities and their institutions.

It is also significant that the teachers in bilingual kindergartens and schools are highly qualified and proficient in both languages of instruction. According to the Act Regulating Special Rights of Members of the Italian and Hungarian Ethnic Communities in the Field of Education, the employment policy must ensure that teachers from both environments are represented in school and kindergarten.

\section{Examples of Research}

Modern researchers have been trying to analyse the basic parameters, efficiency, and results of bilingual education. To achieve this, they attempt to exceed the local and regional frames, as well as put the studies into the concept of the European Union (Bence, 2011; Bernjak, 2004, 2009; Kolláth, 2005, 2009; NečakLük, 2011; Novak-Lukanovič, 2009). Researchers agree that the preferred form of the bilingual education or utopian model of education did not fulfil expectations (Bartha, 2004). This was especially true regarding the preservation of the minority language and forming the national identity of Hungarian students. Reasons include the unfinished didactical side of the educational model and the insufficient competence of the bilingual teachers (Kolláth, 2013). Bilingual education, which is mandatory for both nationalities, has been known as the two-way model to preserve two languages. (NećakLuk, 2013) placed this educational model in Mackey's system. The typology of the bilingual educational programmes considers the two-way model (two-way dual/bilingual, two languages of instruction) as successful and effective (Baker, 1996; García, 1996). Lately, the term two-way immersion (TWI) has been used due to the spreading concept (Cathomas, 2005; García, 2000). In the United States, where this concept in especially popular, it has three objectives: 1) to help students who are not native English speakers achieve better school performance in English classes; 2) to help members of the majority learn the foreign language and develop intercultural sensibility; and 3) to guarantee linguistic and ethnic equality for both communities.

The two most popular program models are the balanced (or 50/50) model, in which instruction for all grade levels is balanced between the two languages (English as the language of majority and the language of minority, Spanish being the most common), and the minority language dominant (or 90/10) model, in which instruction begins with $90 \%$ of the day in the minority language and $10 \%$ 
in English. Various analyses show that the programme successfully results in improved academic results among both majority and minority students. The analytics have discovered that the students in the 50/50 programme achieved higher results in English and Spanish vs. the students in the experimental group. According to the statistics, the results of the minority students with Spanish as their mother tongue who perform the 90/10 model are above average. The results of the majority students whose mother tongue is English cannot be defined as outstanding. Despite the high-level development of linguistic abilities of the majority's mother tongue, the level of achievement of the minority students was higher in terms of vocabulary and grammar knowledge. Linguistic development can be seen with both groups of students. However, the level of achievement was higher with the minority group (Kolláth, 2013).

In her diploma thesis, Sekereš (2009) tried to find differences between the monolingual and bilingual primary education and class preparations. With the descriptive method of the empirical research, she analysed the following: 1) ways to use the languages of instruction; 2) the number of teachers in a classroom; and 3) the differences between the national curriculum and the adjusted national curriculum. In her research, Sekereš (2009) used the descriptive method of the empirical pedagogical research. She found that the preparation of the learning material was written in accordance with the national curriculum. It was the same for both monolingual and bilingual primary schools. The objectives were also written in accordance with the national curriculum (except bilingual preparation material where objectives are also written in Hungarian). There were no differences in preparation methods and forms. The only difference was in the preparation material of the bilingual primary school, which used both Slovenian and Hungarian in the preparation material. Unlike the monolingual primary school, where only one teacher conducts classes, there were two teachers in the second and third grade to conduct classes in the bilingual primary school. Each teacher used one language. One teacher conducted classes in the Slovenian language and taught Slovenian as the mother tongue. The other taught Hungarian. Both teachers used the language they were connected to personally. Rather than translate, they switched from one language to another in certain time intervals.

In another diploma thesis, the author (Klujber, 2014) tried to define the use of Hungarian and Slovenian language in conversations exchanged between the students of the first and second educational period in two small bilingual primary schools in Prekmurje. In her research, the author used the descriptive and causal non-experimental method. Her research pattern included 111 students from the first to the sixth grade of two smaller bilingual primary schools in Prekmurje (Klujber, 2014). Part one of her questionnaire included questions on the school and the class. The second part, which was a closed format, included questions regarding the use of Slovenian and Hungarian language in different conversation situations. The results showed that the use of Slovenian language prevailed among the students of the first and second educational period in both 
schools (Klujber, 2014). Bilingualism was mostly present in the first period. Klujber (2014) felt that it was because of the one person-one language method. The observation showed that the students in both schools used Hungarian and Slovenian language. The language policy played an important role in preserving the minority language. Therefore, it put effort into strengthening its position. In the author's opinion, the law enabled many possibilities for the preservation of the minority language. It is up to the speakers if they will use the language. Family and bilingual schools play an important role in this process.

\section{Conclusion}

This article introduces the regulation of primary education in linguistic and ethnic intersection in Slovenia which is based on a bilingual primary education model. It introduces history development of bilingual model in Slovenia and presents some researches already made or in process in the areas of linguistic and ethnic contacts in Slovenia.

To summarize we can conclude that there can be found enough literature discussing the models of bilingual education. However, researchers noticed a lack of qualitative research and analyses to provide an evaluation of the bilingual model of education on different levels. The role of the minority's educational institutions in terms of preserving Slovenian language and culture should not be insignificant. The national school systems include the minority school systems. Therefore, they often interfere with its mission. On the other hand, it allows them flexibility in choosing teaching methods and content. Highly qualified staff is crucial for successful bilingual educational (Kern, 2009). To avoid the lack of competence among teachers in bilingual schools, Slovenian Ministry of Education, Science and Sport, along with the European Science Fund, has developed the project E-competences. This is coordinated by Pomurje Hungarian Self-Governing Community. E-teaching material helps members of the pedagogical staff in developing Hungarian language competence.

Researchers dealing with the current themes agree that teachers play an important role in a successful bilingual educational process (Bokor, 2009; Kolláth, 2005, 2009; NećakLük, 2011). According to Novak-Lukanovič \& Zver (2013), apart from the bilingual models of education, other factors contribute to the success of bilingual education. These include cooperation between parents, education of bilingual teachers, and establishing policy for integrating the members of majority and minority in the multicultural process. The presence of the minority language in out-of-school activities and in the wider social environment affects the level of success of the bilingual education. Lastly, the economic value of the minority language also plays an important role.

In conclusion we can say that the bilingual model of education is a complex concept deserving of future exploration. Our next step will be to carry out an extensive quantitative research which is already in process. The purpose of mentioned ongoing empirical research is to determine the use of Slovenian and 
Hungarian language in different spoken environments: a home environment and school environment (i.e., in class, socializing with classmates, or conversations with teachers). For example, the partial trial results, based on the trial pattern of 15 students and 10 teachers, showed that in most formal and informal spoken situations among the students, Slovenian language prevails and bilingualism is present occasionally. There are few students who would only use Hungarian language in their conversation. Supporting with theory we can consolidate with Bernjak (2004) who wrote that the minority language is preserved in the family environment because it represents the most common situation where the minority language is used. The ongoing research will give us a quantitative empirical insight into the state of bilingual education and its challenges. Based on the additional findings and findings from this article, we expect to be able to adjust the methods of primary education and plan additional training for the teachers.

\section{References}

Anckar, O. (2000). University Education in a Bilingual Country: The Case of Finland. Higher Education in Europe, 25, 499-506. https://doi.org/10.1080/03797720120037831

Baker, C. (1996). Foundations of Bilingual Education and Bilingualism (2nd ed.). Clevedon, UK: Multilingual Matters.

Bartha, C. (2004). Kétnyelvűség, oktatás, kétnyelvűoktatáséskisebbségek. A hetvenéves Szépe Györgynek. Educatio [Education], 2004, 761-775.

Bence, L. (2011). A kétnyelvűoktatástörténete. In M. Király (Ed.), 50 éves a kétnyelvüoktatás a Muravidéken [50 Years of Bilingual Education in the Murmansk Region] (pp. 13-51). Lendava, Slovenia: Magyar Nemzetiségi TájékoztatásiIntézet.

Bernjak, E. (2004). A kisebbséginyelvekjövőjeaz EU-ban: nyelvcserevagynyelvirevitalizáció [The Future of Minority Languages in the EU: Language Change or Linguistic Revival]. Kisebbségkutatás: Szemle a hazaiéskülföldiirodalomból [Minority Research: A Review of Domestic and Foreign Literature], 13, 221-228.

Bernjak, E. (2009). Medkulturna paradigma slovenistike v medkulturnem okolju. In M. Stabej (Ed.). Infrastrukturaslovenščine in slovenistike. Simpozij 28 [Symposium 28] (pp. 57-63). Ljubljana: Znanstvenazaložba Filozofskefakultete.

Bokor, J. (2009). Nyelviség és magyarság a Muravidéken [Language and Hungarians in the Muravidék]. Lendava, Slovenia: Magyar Nemzetiségi MűvelődésiIntézet.

Cathomas, R. (2005). Schule und Zweisprachigkeit [School and Bilingualism]. Munster, Germany: Waxmann Verlag GmbH.

Constitution of the Republic of Slovenia, Official Gazette RS Nos. 33/91-I, 42/97, 66/2000, 24/03, 69/04, 68/06, and 47/13 (2016). http://www.us-rs.si/en/about-the-court/legal-basis/

García, E. (2000). Student Cultural Diversity. Understanding and Meeting the Challenge. Boston, MA: Houghton Mifflin.

García, O. (1996). Bilingual Education. In F. Coulmas (Ed.), The Handbook of Sociolinguistics (pp. 405-420). Oxford, UK: Blackwell.

Hozjan, B. (2009). O dvojezičnem šolstvu na narodnostno mešanem območju [About Bilingual Education in the Ethnically Mixed Area]. www.dos1-lendava.si/DOS/images/dokumenti_tbv/dvojezicno_solstvo.doc

Kern, D. (2009). Vloga manjšinske šole pri ohranjanju slovenskega jezika in kulture [The 
role of Minority School in Preserving Slovene Language and Culture]. Jezik in slovstvo [Language and Literature], 1, 55-71.

Klujber, D. (2014). Jezik v 1. In 2.VIO nadvojezičniosnovnišoli [Teaching at a Bilingual Primary School]. Diploma Thesis, Maribor, Slovenia: Pedagoškafakulteta.

Kolláth, A. (2005). Magyarul a Muravidéken [In the Mura Region]. Maribor, Slovenia: Slavistično društvo Zora 39.

Kolláth, A. (2009). Kétnyelv és oktatás. In A. Kollath (Ed.), A Half a Century of Bilingual Education in Muravidék (pp. 36-59). Bielsko-Biała, Budapest, Kansas, Maribor, Praha: Zora 68.

Kolláth, A. (2013). Nekaj misli o modelih dvojezičnega poučevanja. In M. Pisnjak, M. Berden, \& J. Novak Csaszar (Eds.), Manual for Teachers of Bilingual Schools in Prekmurje (pp. 535-597). Lendava: Zavodzakulturomadžarskenarodnosti.

Mikolič, V. G. (2000). Links between National and Language Identity Awareness. Languageand Literature, 5, 173-186.

NećakLük, A. (2010). Iz preteklosti za prihodnost: Pol stoletja dvojezičnega šolstva v Prekmurju. In J. Herman, T. Sabo, M. Pisnjak, \& E. KiralyPatyi (Eds.), With Each Other: On the Occasion of the 50th Anniversary of Bilingual Education in the Ethnically Mixed Area in Prekmurje (pp. 15-27). Lendava: Dvojezični vzgojno-izobraževalni zavodi na asnarodnostno mešanem območju v Prekmurju.

NećakLük, A. (2011). Tény, hogy a magyarnyelvetelsősorban a kisebbségnek kell használnia. In M. Király (Ed.), 50 Years of Bilingual Education in the Murmansk Region (pp. 120-125). Lendava: Magyar Nemzetiségi Tájékoztatási Intézet.

NećakLük, A. (2013). Metodologijajezikovneorganizacijedvojezičnegapouka. In M. Pisnjak, M. Berden, \& J. Novak Csaszar (Eds.), Manual for Teachers of Bilingual Schools in Prekmurje (pp. 20-27). Lendava: Zavodzakulturomadžarskenarodnosti.

Novak-Lukanovič, S. (2009). Stališčaučencev do modelovizobraževanja. In L. Čok (Ed.), Education for Bilingualism in the Context of European Integration Processes. The Effectiveness of Bilingual Education Models in the Ethnically Mixed Environments of Slovenia (pp. 149-171). Koper: ZaložbaAnnales.

Novak-Lukanovič, S., \& Zver, S. (2013). Dvojezično izobraževanje: Izbrani primeri v svetu. In M. Pisnjak, M. Berden, \& J. Novak Csaszar (Eds.), Manual for Teachers of Bilingual Schools in Prekmurje (pp. 500-534). Lendava: Zavodzakulturomadžarskenarodnosti.

Ouane, A. (2003). Towards a Multilingual Culture of Education. Hamburg: UNESCO Institute for Education.

Sekereš, G. (2009). Language in the 1st and 2nd Cycle at the Bilingual Elementary School. Diploma Thesis, Maribor: Pedagoškafakulteta.

Smith, A. D. (1991). Genealogy of Nations. In R. Rizman (Ed.), Studies on Ethno-Nationalism (pp. 51-77). Ljubljana: Knjižnicarevolucionarneteorije.

Varga, Š., Šebjanič, V., Tot Savinec, M., Hozjan, B., Milekšič, V., Kumer, I. et al. (2005). Implementation Instructions. Implementation of the 9-Year Bilingual Elementary School Program. Ljubljana: Zavod republike Slovenije za šolstvo. 